DOI: https://doi.org/10.31933/jemsi.v2i3

Received: 21 November2020, Revised: 20 Desember 2020, Publish: 8 Februari 2021

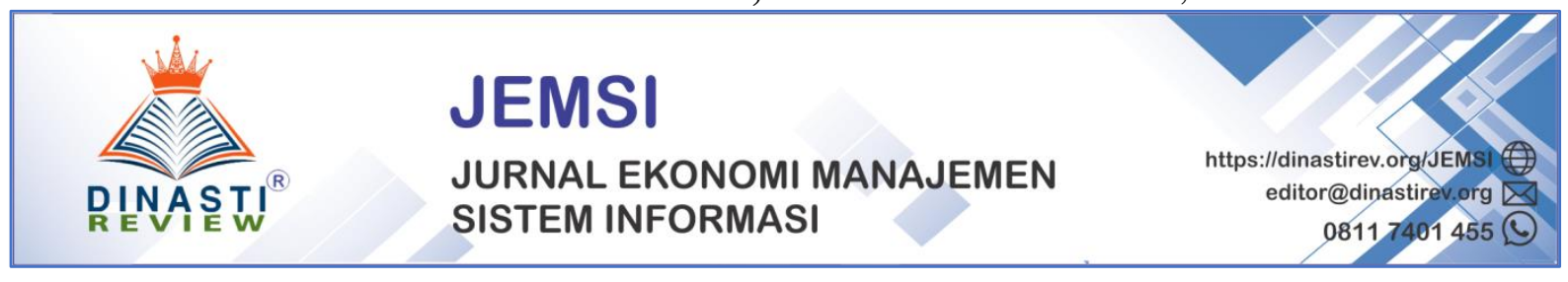

\title{
ANALISIS RASIO LIKUIDITAS, SOLVABILITAS, AKTIVITAS, DAN PROFITABILITAS PT. ALAM SUTERA REALTY, TBK. (ASRI) PERIODE 2014-2019
}

\author{
Ariela Griselda \\ Program Studi Magister Manajemen Universitas Mercu Buana, Jakarta, arielagriselda@yahoo.com
}

\section{Corresponding Author: Ariela Griselda}

Abstrak: Penelitian ini bertujuan untuk mengetahui kinerja keuangan PT. Alam Sutera Realty, Tbk. (ASRI) yang diukur dengan menggunakan rasio likuiditas (current ratio), rasio solvabilitas (total debt ratio dan debt equity ratio), rasio aktifitas (receivables turnover dan total asset turnover), dan rasio profitabilitas (profit margin dan return on equity). Data yang digunakan dalam penelitian ini adalah laporan keuangan PT. Alam Sutera Realty, Tbk. dari tahun 2014 hingga 2019. Metode analisis dalam penelitian ini adalah analisis statistik deskriptif yang digunakan untuk menjelaskan rasio-rasio keuangan perusahaan.

Kata Kunci: likuiditas, solvabilitas, aktivitas, profitabilitas

\section{PENDAHULUAN}

Laporan keuangan mencerminkan kinerja perusahaan selama periode tertentu sehingga dapat dijadikan acuan dalam pengambilan keputusan oleh para pengguna laporan keuangan. Menurut IAI dalam PSAK No. 1 Tahun 2015 menyatakan bahwa pengguna laporan keuangan meliputi investor sekarang dan investor potensial, karyawan, pemberi pinjaman, pemasok, dan usaha kreditor lainnya, pelanggan, pemerintah serta lembaga-lembaga lainnya dan masyarakat. Analisis kinerja keuangan perusahaan dapat digunakan sebagai alat untuk mengukur kemampuan perusahaan yang dapat dilakukan dalam satu atau beberapa periode. Analisis Common Size, Trend Index, dan Rasio merupakan pendekatan yang dapat diterapkan untuk mengetahui kinerja keuangan dengan melakukan analisis antar waktu, yang disebut juga analisis dinamis. Ukuran yang paling sering dipakai dalam menganalisis kinerja keuangan perusahaan ialah analisis rasio. Analisis rasio keuangan dapat memberikan gambaran perkembangan suatu perusahaan saat ini dan di masa yang akan datang untuk melihat sehat atau tidaknya kinerja keuangan suatu perusahaan.

Rasio keuangan yang umum digunakan dalam mengukur kinerja keuangan perusahaan adalah rasio likuiditas, solvabilitas dan profitabilitas (Munawir, 2010). Rasio likuiditas yang digunakan adalah current ratio, karena current ratio adalah rasio yang paling umum digunakan dalam analisis laporan keuangan dan memberikan ukuran kasar tentang tingkat likuiditas perusahaan secara menyeluruh (Jumingan, 2009). Rasio solvabilitas yang digunakan adalah debt ratio, karena debt ratio dapat melihat kemampuan perusahaan dalam menutupi utangnya ketika perusahaan dilikuidasi (Kasmir, 2010). Rasio aktifitas yang digunakan ialah receivables turnover dan total asset turnover. Sedangkan rasio profitabilitas yang digunakan adalah profit margin dan return on equity. 
PT. Alam Sutera Realty Tbk merupakan perusahaan Indonesia yang bergerak di bidang real estate yang mengembangkan dan memanajemen property-properti tempat tinggal, tempat usaha komersil, tempat industri, dan pusat perbelanjaan, kantor dan juga tempat rekreasi. Saham perusahaan ini masuk dalam Listing saham Bursa Efek Indonesia(BEI). Seiring dengan bertumbuhnya peningkatan penduduk dari waktu ke waktu, investor yakin bahwa bisnis di bidang property memiliki prospek yang bagus karena pertumbuhan penduduk berarti bahwa menngkat pula kebutuhan akan tempat tinggal.

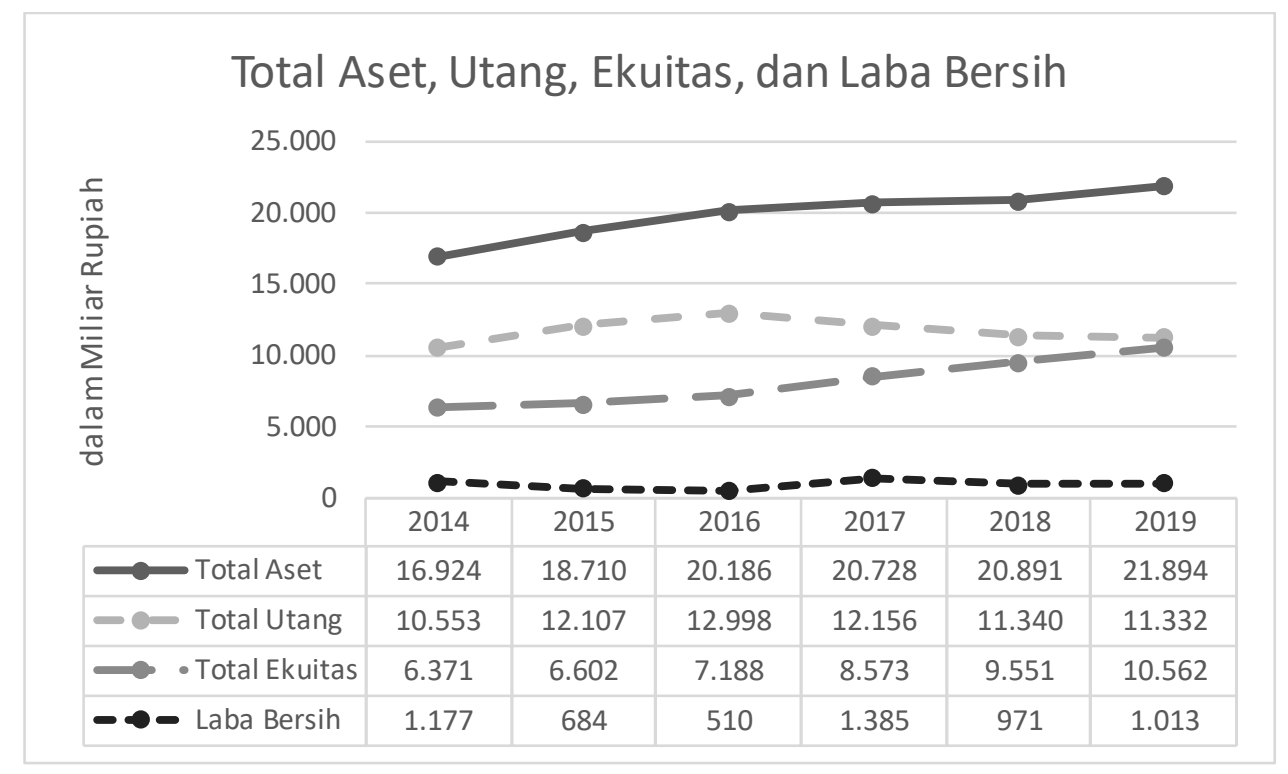

\section{Grafik 1. Pertumbuhan total Aset, Utang, Ekuitas, dan Laba Bersih ASRI}

Berdasarkan grafik 1 terlihat bahwa total aset selalu mengalami pertumbuhan setiap tahunnya dari tahun 2014 hingga 2019. Sedangkan total utang naik dari tahun 2014 hingga 2016, kemudian mengalami penurunan dari tahun 2017 hingga 2019. Total ekuitas selalu naik dari tahun 2014 hingga 2019. Sedangkan laba bersih mengalami penuruan dari tahun 2014 hingga 2016, kemudian naik lagi pada tahun 2017, turun lagi pada tahun 2018, dan naik lagi pada tahun 2019. Penelitian ini bertujuan untuk mengetahui dan menganalisis kinerja keuangan PT. Alam Sutera Realty Tbk. Dalam hal ini peneliti tertarik untuk menjadikan PT. Alam Sutera Realty, Tbk. sebagai objek penelitian untuk menilai apakah perusahaan memiliki tingkat likuiditas, solvabilitas, aktivitas dan profitabilitas yang baik.

\section{KAJIAN PUSTAKA}

\section{Analisis Rasio Keuangan}

Sunyoto (2013) menyatakan bahwa analisis rasio keuangan merupakan suatu proses analisa yang dapat dijadikan tolak ukur untuk menilai kinerja sebuah perusahaan. Rasio keuangan sering kali digunakan sebagai alat untuk mengukur dan menilai kinerja perusahaan untuk kemudian dianalisa mengenai kemungkinan-kemungkinan hasil yang akan diperoleh dari investasi yang dilakukan. Astuti (2004) mengatakan bahwa analisis rasio keuangan dirancang untuk membantu mengevaluasi laporan keuangan. Dalam perhitungan analisis rasio digunakan data yang terdapat dalam neraca dan laporan laba rugi. Analisis rasio tidak sematamata menggunakan data yang ada di neraca dan laporan laba rugi dan dimasukkan ke berbagai rumus perhitungan, namun yang lebih penting adalah membaca dan mengerti hasil analisis rasio tersebut.

\section{Rasio Likuiditas}


Rasio likuiditas digunakan untuk mengukur kemampuan perusahaan dalam memenuhi kewajiban finansial jangka pendek. Apabila perusahaan memiliki kemampuan yang cukup untuk membayar utang jangka pendeknya, maka perusahaan tersebut disebut likuid, sedangkan apabila perusahaan tidak mampu untuk membayar utang jangka pendeknya, maka perusahaan disebut ilikuid.

Current Ratio

Rasio ini dapat ditentukan dengan membandingkan Aktiva Lancar dengan Utang Lancar dikali $100 \%$.

\section{Current Ratio = Aktiva Lancar : Utang Lancar X $100 \%$}

Pedoman atau standar umum yang digunakan untuk current ratio adalah $2: 1$. Jika CR sama atau lebih besar dari standar tersebut dapat dikatakan likuid, dan sebaliknya jika lebih kecil dari $200 \%$ dinilai ilikuid atau tidak likuid.

\section{Rasio Solvabilitas}

Suatu perusahaan dikatakan solvable apabila perusahaan tersebut memiliki aktiva atau kekayaan yang cukup untuk membayar semua utang-utangnya, sebaliknya apabila jumlah aktiva tidak cukup atau lebih kecil daripadajumlah utangnya, maka perusahaan dalam keadaan insolvable.

\section{Total Debt Ratio}

Total Debt Ratio merupakan rasio utang yang digunakan untuk mengukur seberapa besar aktiva perusahaan dibiayai oleh utang atau seberapa besar utang perusahaan berpengaruh terhadap pengelolaan aktiva.

\section{Total Debt Ratio $=$ Total Utang : Total Aktiva X $100 \%$}

\section{Debt Equity Ratio}

Rasio ini dapat ditentukan dengan membandingkan antara Total Utang dengan Total Ekuitas dikali 100\%.

\section{Debt Equity Ratio = Total Utang : Total Ekuitas X 100\%}

Suatu perusahaan dikatakan solvable apabila nilai Debt to Equity Ratio (DER ) tidak melebihi $100 \%$ atau 1, dan jika nilai Debt to Equity Ratio melebihi $100 \%$ atau 1, maka perusahaan tersebut bisa dikatakan insolvable.

\section{Rasio Aktivitas}

Rasio aktivitas merupakan rasio yang mengukur efektivitas perusahaan dalam menjalankan operasionalnya .

Receivables Turn Over

Rasio ini menunjukkan berapa cepat penagihan piutang oleh perusahaan

$$
\text { Receivables Turn Over }=\text { Penjualan }: \text { Piutang }
$$

\section{Total asset turn over}

Rasio ini menunjukan perputaran total aktiva diukur dari volume penjualan dengan kata lain seberapa jauh kemampuan semua aktiva menciptakan penjualan. 
Total Asset Turn Over = Penjualan : Total Aset

\section{Rasio Profitabilitas}

Analisis Rasio Profitabilitas adalah alat untuk mengukur tingkat efektifitas pengelolaan perusahaan yang ditunjukan oleh jumlah keuntungan yang dihasilkan dari penjualan dan investasi. Rasio ini menunjukan kemampuan perusahaan untuk menghasilkan laba selama periode tertentu.

Profit Margin

Semakin tinggi profit margin, semakin baik karena menunjukkan perusahaan yang efisien dalam hal biaya yang rendah.

\section{Profit Margin = Laba Bersih : Penjualan X $100 \%$}

\section{Return on Equity}

Rasio ini dapat ditentukan dengan membandingkan antara Laba Barsih Sesudah Pajak dengan Total Ekuitas dikali 100\%.

Return on Equity = Laba Bersih Setelah Pajak : Total Ekuitas X 100\%

Semakin besar nilai Return on Equity, maka semakin baik karena hal ini menunjukan besar modal sendiri dalam menghasilkan sejumlah laba.

\section{Keunggulan dan Kelemahan Analisis Rasio Keuangan}

Keunggulan-keunggulan analisis rasio keuangan menurut Harahap (2009: 195), kegunaan analisis laporan keuangan ini dapat dikemukakan sebagai berikut:

a. Dapat memberikan informasi yang lebih luas, lebih dalam dari pada yang terdapat dari laporan keuangan biasa.

b. Dapat menggali informasi yang tidak tampak secara kasat mata (explicit) dari suatu laporan keuangan atau yang berada di balik laporan keuangan (implicit).

c. Dapat mengetahui kesalahan yang terkandung dalam laporan keuangan.

d. Dapat membongkar hal-hal bersifat tidak konsisten dalam hubungannya dengan suatu laporan keuangan baik dikaitkan dengan komponen intern maupun kaitannya dengan informasi yang diperoleh dari luar perusahaan.

e. Mengetahui sifat-sifat hubungan yang akhirnya dapat melahirkan modelmodel dan teori-teori yang terdapat di lapangan seperti untuk prediksi dan peningkatan.

Ada beberapa kelemahan dengan dipergunakannya analisis secara rasio keuangan yaitu:

a. Penggunaan rasio keuangan akan memberikan pengukuran yang relatif terhadap kondisi suatu perusahaan.

b. Analisis rasio keuangan hanya dapat dijadikan sebagai peringatan awal dan bukan kesimpulan akhir.

c. Setiap data yang diperoleh yang dipergunakan dalam menganalisis adalah bersumber dari laporan keuangan perusahaan sehingga angka data-datanya tidak memiliki keakuratan yang tinggi dengan alasan.

d. Mungkin data-data tersebut dirubah dan disesuaikan berdasarkan kebutuhan. 
e. Pengukuran rasio keuangan banyak yang bersifat artifical, artifical artinya perhitungan rasio keuangan tersebut dilakukan oleh manusia, dan setiap pihak memiliki pandangan yang berbeda-beda dalam menempatkan ukuran dan terutama justifikasi dipergunakannya rasiorasio tersebut.

f. Membandingkan rasio antar perusahaan dapat menyebabkan interpretasi yang keliru, hal ini karena dimungkinkan terjadi perbedaan metode akuntansi yang dipakai misalnya depresiasi, pengakuan pendapatan, serta aset tak berwujud.

\section{Analisis DuPont}

Analisis Du Pont System merupakan model analisis yang menyangkut rasio aktivitas yaitu Total Assets Turnover(TATO), rasio solvabilitas yaitu Equity Multiplier (EM) dan beberapa rasio profitabilitas seperti Net Profit Margin (NPM), Return On Asset (ROA) dan Return On Equity (ROE). Keunggulan dari dilakukannya analisis DuPont System antara lain (1) sebagai salah satu teknik analisis keuangan yang sifatnya menyeluruh dan manajemen dapat mengetahui tingkat efisiensi pendayagunaan aktiva, selain itu (2) dapat digunakan untuk mengukur profitabilitas masing-masing produk yang dihasilkan oleh perusahaan sehingga diketahui produk mana yang potensial, serta (3) menganalisis laporan keuangan menggunakan pendekatan yang lebih integratif dan menggunakan laporan keuangan sebagai elemen analisisnya. Adapun kekurangan dari model analisis ini antara lain (1) ROI suatu perusahaan sulit dibandingkan dengan ROI perusahaan lain yang sejenis, karena adanya perbedaan praktek akuntansi yang digunakan, selain itu (2) dengan menggunakan ROI saja tidak akan dapat digunakan untuk mengadakan perbandingan antara dua permasalahan atau lebih dengan mendapatkan kesimpulan yang memuaskan (Harahap dalam Surono dkk, 2019: 18).

\section{METODE PENELITIAN}

\section{Jenis Data}

Penelitian ini menggunakan data kualitatif berupa teori-teori dan gambaran umum PT. Alam Sutera Realty Tbk. yang digunakan untuk mengembangkan analisis rasio likuiditas, solvabilitas, aktivitas, dan profitabilitas dalam mengukur kinerja keuangan PT. Alam Sutera Realty Tbk.

\section{Sumber Data}

Sumber data yang digunakan pada penelitian ini ialah data sekunder yang diperoleh melalui internet, buku-buku, dan jurnal yang berhubungan dengan penelitian.

\section{Metode Pengumpulan Data}

Penelitian ini menggunakan metode pengumpulan data berupa penelitian kepustakaan dan dokumen berupa data laporan keuangan perusahaan dari tahun 2014-2019 yang diperoleh dari Bursa Efek Indonesia yang diunduh melalui situs www.idx.co.id

\section{Metode Analisis Data}

Metode analisis data yang digunakan dalam penelitian ini adalah analisis statistik deskriptif. Menurut Sugiyono (2014), penelitian statistik deskriptif yaitu analisis data dengan cara mendeskripsikan atau menggambarkan data yang telah terkumpul sebagaimana adanya tanpa bermaksud membuat kesimpulan yang berlaku untuk umum. Penelitian ini membandingkan rasio-rasio keuangan sebagai berikut: 
Rasio Likuiditas

Current Ratio

Current Ratio = Aktiva Lancar : Utang Lancar X $100 \%$

\section{Rasio Solvabilitas}

Total Debt Ratio

Total Debt Ratio = Total Utang : Total Aktiva X $100 \%$

Debt Equity Ratio

Debt Equity Ratio = Total Utang : Total Ekuitas X $100 \%$

\section{Rasio Aktivitas}

Receivables Turn Over

$$
\text { Receivables Turn Over }=\text { Penjualan }: \text { Piutang }
$$

Total asset turn over

$$
\text { Total Asset Turn Over = Penjualan }: \text { Total Aset }
$$

\section{Rasio Profitabilitas}

Profit Margin

Profit Margin = Laba Bersih : Penjualan X $100 \%$

Return on Equity

Return on Equity = Laba Bersih Setelah Pajak : Total Ekuitas X 100\%

HASIL PENELITIAN DAN PEMBAHASAN

Tabel 1. ANALISIS RASIO ASRI 


\begin{tabular}{|c|c|c|c|c|c|c|c|}
\hline Jenis Rasio & Rumus & 2014 & 2015 & 2016 & 2017 & 2018 & 2019 \\
\hline \multicolumn{8}{|c|}{ LIKUIDITAS (satuan: kali) } \\
\hline \multirow{2}{*}{ Current Ratio } & Aktiva Lancar & \multirow{2}{*}{1,14} & \multirow{2}{*}{0,72} & \multirow{2}{*}{0,90} & \multirow{2}{*}{0,74} & \multirow{2}{*}{0,65} & \multirow{2}{*}{1,31} \\
\hline & Utang Lancar & & & & & & \\
\hline \multicolumn{8}{|c|}{ SOLVABIUTAS (satuan: kali) } \\
\hline \multirow{2}{*}{ Total Debt Ratio } & Total Aktiva - Total Ekuitas & \multirow{2}{*}{0,62} & \multirow{2}{*}{0,65} & \multirow{2}{*}{0,64} & \multirow{2}{*}{0,59} & \multirow{2}{*}{0,54} & \multirow{2}{*}{0,52} \\
\hline & Total Aktiva & & & & & & \\
\hline \multirow{3}{*}{ Debt Equity Ratio } & & \multirow{3}{*}{1,66} & \multirow{3}{*}{1,83} & \multirow{3}{*}{1,81} & \multirow{3}{*}{1,42} & \multirow{3}{*}{1,19} & \multirow{3}{*}{1,07} \\
\hline & Total Utang & & & & & & \\
\hline & Total Ekuitas & & & & & & \\
\hline \multicolumn{8}{|c|}{ AKTIVITAS } \\
\hline \multirow{2}{*}{$\begin{array}{c}\text { Receivables Turn Over } \\
\text { (satuan: kali) }\end{array}$} & Penjualan & \multirow{2}{*}{19,05} & \multirow{2}{*}{18,48} & \multirow{2}{*}{13,62} & \multirow{2}{*}{16,79} & \multirow{2}{*}{16,98} & \multirow{2}{*}{33,04} \\
\hline & Piutang & & & & & & \\
\hline \multirow{3}{*}{$\begin{array}{c}\text { Total Asset Turn Over } \\
\text { (satuan: kali) }\end{array}$} & & \multirow{3}{*}{0,21} & \multirow{3}{*}{0,15} & \multirow{3}{*}{0,13} & & & \\
\hline & Penjualan & & & & 0.19 & 0.19 & 0.16 \\
\hline & Total Aktiva & & & & 0,19 & 0,19 & \\
\hline & PROFITABILI & AS (sat & $n: \%)$ & & & & \\
\hline Pmfit Marmin & Laba Bersih & $33 \%$ & $25 \%$ & $10 \%$ & $35 \%$ & $20 \%$ & $29 \%$ \\
\hline Projit Margin & Penjualan & $32 \%$ & $23 \%$ & $19 \%$ & $35 \%$ & $24 \%$ & $29 \%$ \\
\hline Return On Fouity & Laba Bersih & & $10 \%$ & & & & \\
\hline Return on Equity & Total Ekuitas & $18 \%$ & $10 \%$ & $1 \%$ & $16 \%$ & $10 \%$ & $10 \%$ \\
\hline
\end{tabular}

\section{Analisa Likuiditas}

\section{Current Ratio}

Berikut adalah grafik Current Ratio pada PT. Alam Sutera Realty Tbk.

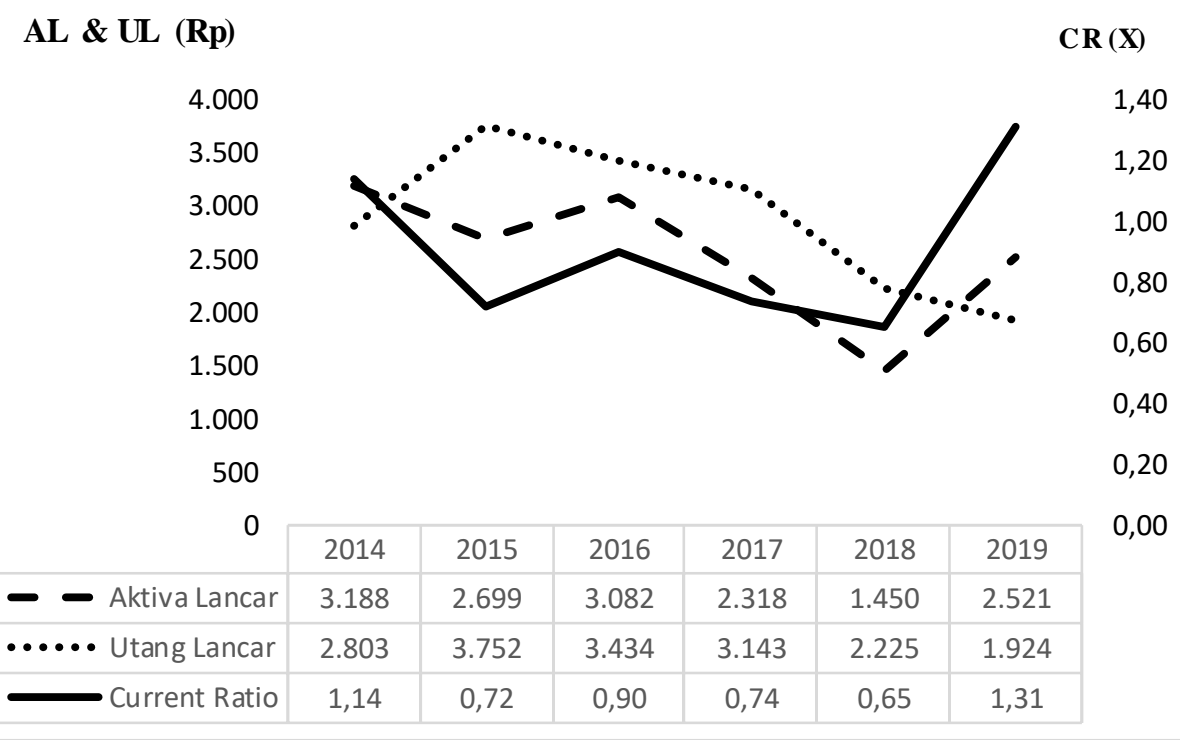

\section{Grafik 2. Perbandingan Aset Lancar, Utang Lancar, dan Current Ratio ASRI}

Current ratio merupakan perbandingan antara aset lancar dengan utang lancar. Rasio lancar digunakan untuk melihat seberapa besar kemampuan perusahaan untuk melunasi kewajiban lancar menggunakan aset lancar yang dimiliki atau seberapa besar jaminan aset lancar untuk memenuhi kewajiban lancar. Semakin besar perbandingan aktiva lancar dengan 
utang lancar, semakin tinggi kemampuan perusahaan menutupi kewajiban jangka pendeknya. Rasio lancar yang baik umumnya adalah diatas 1 kali, karena hal tersebut menandakan bahwa perusahaan memiliki aset lancar yang lebih besar daripada kewajiban lancar. Semakin besar rasio lancar, maka likuiditas perusahaan dapat dikatakan semakin bagus.

Berdasarkan grafik 2 dapat terlihat bahwa Current Ratio PT. Alam Sutera Realty, Tbk fluktuatif dari tahun ke tahun. Current ratio dengan nilai $>1$ menunjukkan bahwa aktiva lancar $>$ hutang lancar yang berarti bahwa perusahaan dianggap mampu memenuhi segala kewajiban jangka pendeknya. PT. Alam Sutera Realty, Tbk memiliki nilai current ratio yang baik pada tahun 2014 dan 2019. Sedangkan pada tahun 2015 hingga 2018, nilai current ratio < 1 yang berarti bahwa perusahaan belum mampu memenuhi segala kewajiban jangka pendeknya. Nilai rata-rata current ratio PT. Alam Sutera Realty, Tbk dari tahun 2014 hingga 2019 ialah 0,91. Namun angka current ratio < 1 tidak selalu menunjukkan bahwa perusahaan sedang di ambang kebangkrutan, karena perusahaan tersebut mungkin masih memiliki sumber dana lainnya. Pada grafik pun terlihat nilai current ratio pada tahun 2019 naik cukup drastis dibandingkan tahun sebelumnya. Sehingga dapat disimpulkan bahwa PT. Alam Sutera Realty, Tbk. mampu untuk memenuhi segala kewajiban jangka pendeknya selama periode 2014 hingga 2019.

\section{Analisa Solvabilitas}

Total Debt Ratio

Berikut adalah grafik Total Debt Ratio_pada PT. Alam Sutera Realty Tbk.

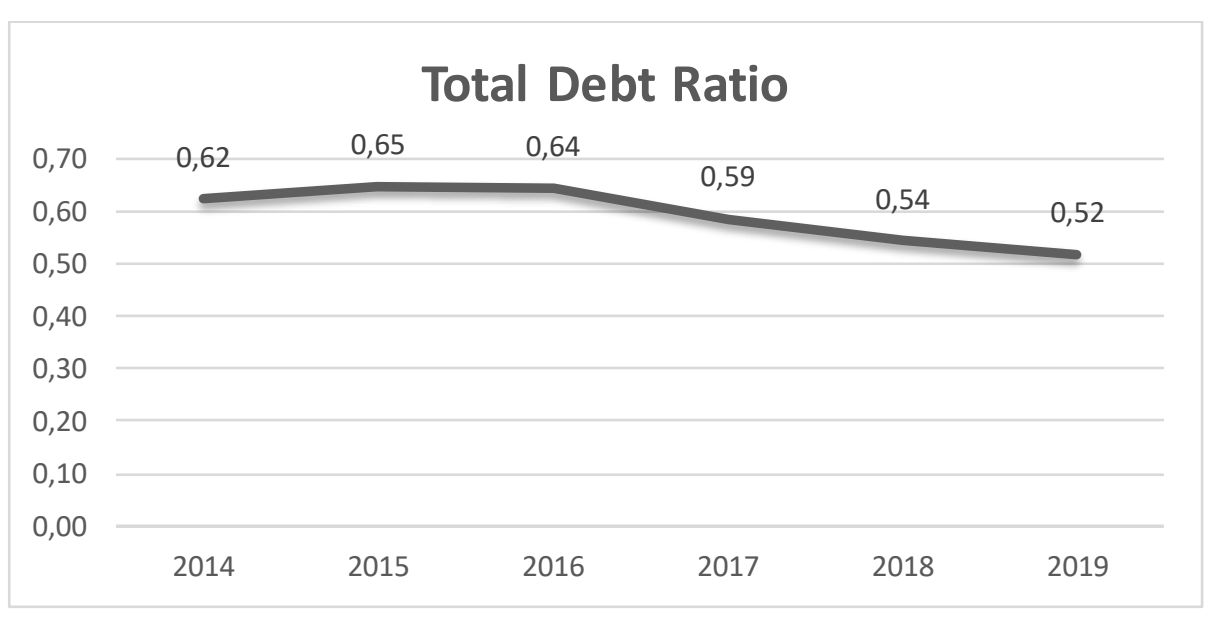

\section{Grafik 3. Total Debt Ratio ASRI}

Semakin besar nilai total debt ratio, berarti bahwa aktiva yang dimiliki oleh perusahaan dibeli atau dibiayai dengan menggunakan hutang dan berarti semakin besar pula risiko bagi para kreditur atau pihak yang memberikan pinjaman kepada perusahaan. Nilai rata-rata total debt ratio PT. Alam Sutera Realty, Tbk. selama enam tahun adalah 0,59. Pada grafik 3 terlihat bahwa nilai total debt ratio PT. Alam Sutera Realty, Tbk. pada tahun 2014 hingga 2016 mengalami kenaikkan, namun mengalami penurunan dari tahun 2016 hingga 2019 yang berarti bahwa menurun pula risiko bagi para kreditur.

\section{Debt Equity Ratio}

Berikut adalah grafik Debt Equity Ratio pada PT. Alam Sutera Realty Tbk. 


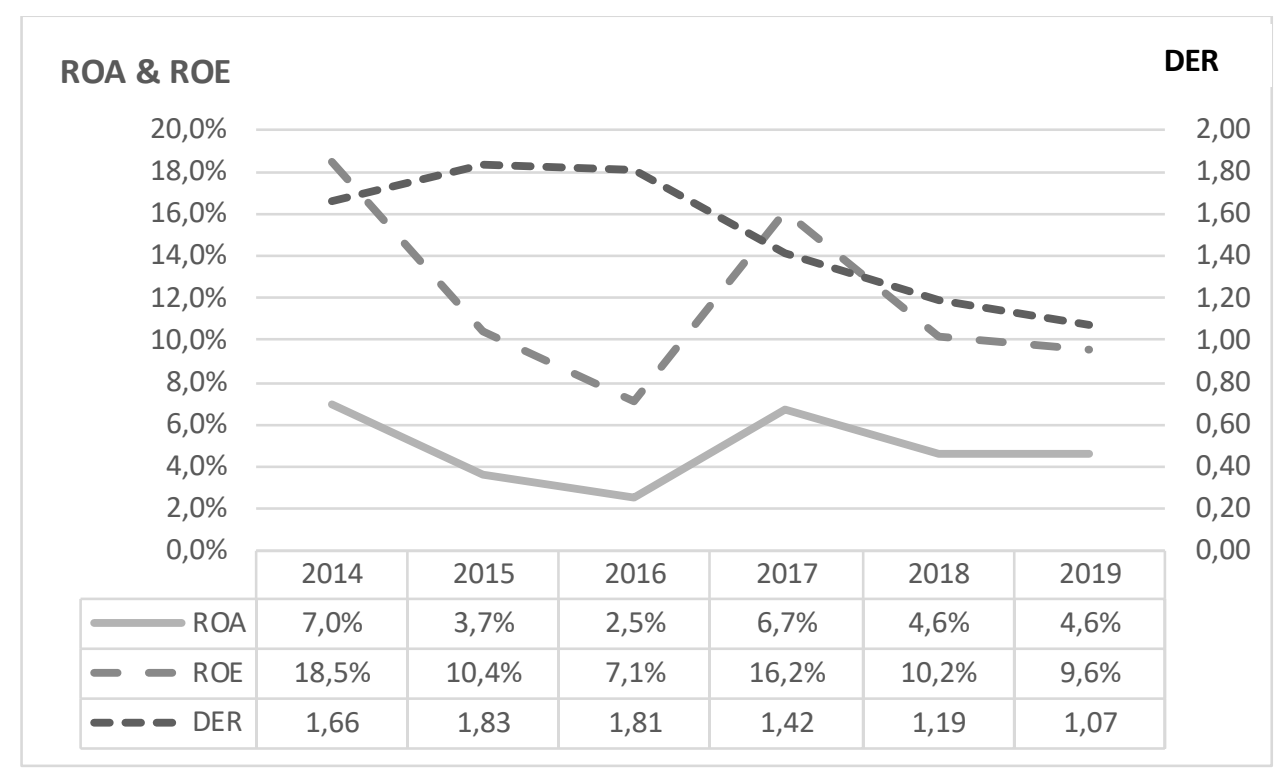

\section{Grafik 4. Perbandingan ROA, ROE, dan DER ASRI}

Debt equity ratio menunjukkan seberapa besar ekuitas atau modal yang dimiliki oleh perusahaan dibiayai oleh hutang. Semakin besar nilai rasio ini berarti bahwa modal yang dimiliki oleh perusahaan berasal dari pinjaman sehingga semakin besar rasio ini maka semakin besar pula risiko bagi para kreditur perusahaan. Nilai rata-rata debt equity ratio PT. Alam Sutera Realty, Tbk. selama enam tahun adalah 1,50. Padagrafik 4 terlihat nilai debt equity ratio PT. Alam Sutera Realty, Tbk. naik dari tahun 2014 hingga 2016, namun kian menurun dari tahun 2016 hingga 2019 yang berarti menurun pula risiko bagi para kreditur perusahaan.

\section{Rasio Aktivitas}

Receivables Turnover

Berikut adalah grafik Receivables Turnover pada PT. Alam Sutera Realty Tbk.

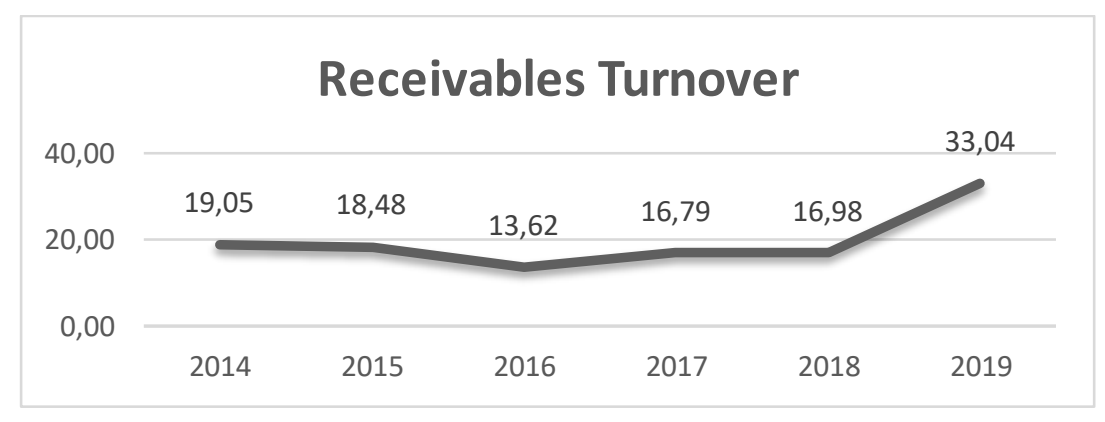

\section{Grafik 5. Receivables Turnover ASRI}

Receivable Turnover menunjukkan berapa kali suatu perusahaan melakukan tagihan atas piutangnya pada suatu periode tertentu. Semakin tinggi nilainya semakin banyak piutang yang dapat ditagih oleh perusahaan dan semakin kecil juga kemungkinan ad anya piutang yang tidak tertagih serta akan memperlancar arus kas. Nilai rata-rata receivables turnover PT. Alam Sutera Realty, Tbk. adalah 19,66. Pada grafik 5 terlihat bahwa pada tahun 2014 hingga 2018, nilai receivables turnover PT. Alam Sutera Realty, Tbk. cenderung naik turun dengan angka yang tidak signifikan. Namun dari tahun 2018 ke 2019, nilai receivables turnover naik signifikan yang berarti bahwa perusahaan memiliki kemampuan yang baik dalam menagih piutangnya. 
Total Asset Turnover, Profit Margin, dan ROA

Berikut adalah grafik Total Asset Turnover, Profit Margin, dan ROA pada PT. Alam Sutera Realty Tbk.

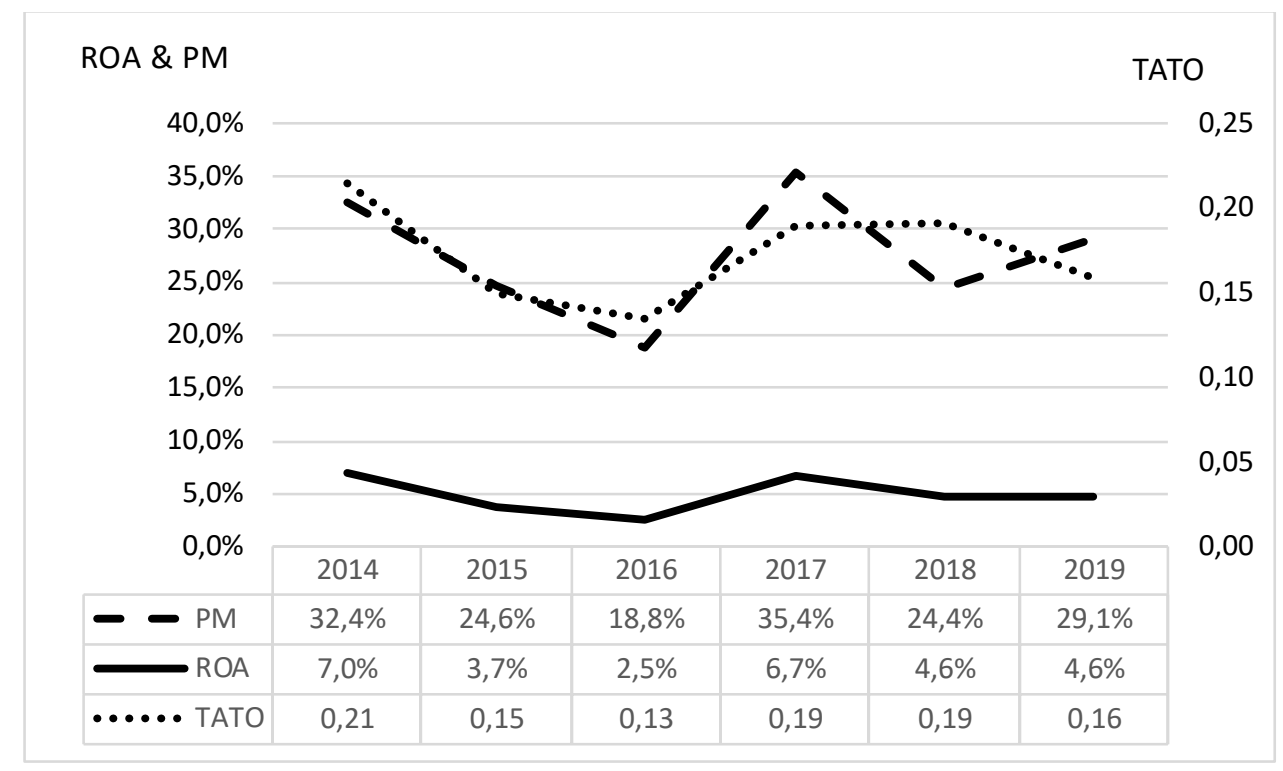

Grafik 6. Perbandingan ROA, PM, dan TATO ASRI

Total Asset Turnover menunjukkan kemampuan perusahaan dalam mengelola seluruh aset yang dimiliki untuk menghasilkan penjualan. Semakin tinggi nilainya, semakin tinggi pula penjualan yang dilakukan oleh perusahaan dari hasil mengelola aset yang dimilikinya dan dapat dikatakan bahwa perusahaan tersebut produktif. Pada grafik 6 terlihat nilai total aset turnover PT. Alam Sutera Realty, Tbk. turun dari tahun 2014 hingga 2016, dan tetap memiliki nilai yang bervariasi namun tetap di bawah nilai total aset turnover pada tahun 2014. Nilai rata-rata total asset turnover PT. Alam Sutera Realty, Tbk. selama enam tahun ialah 0,17.

\section{Analisa Profitabilitas}

\section{Profit Margin}

Profit margin menunjukkan seberapa besar keuntungan yang dapat diperoleh perusahaan dari aktivitas penjualan yang dilakukan, atau dapat juga dikatakan bahwa rasio ini menunjukkan seberapa efektif dan efisiennya perusahaan dalam mengelola biaya dalam proses penjualan sehingga dapat memperoleh laba yang lebih tinggi dari hasil penjualan. Semakin tinggi nilai profit margin perusahaan maka semakin baik. Pada grafik 6 terlihat nilai profit margin PT. Alam Sutera Realty, Tbk. berfluktuatif dari tahun 2014 hingga 2019 dengan nilai rata-rata $27 \%$. Dapat disimpulkan bahwa perusahaan masih dinilai cukup efektif dan efisien dalam melakukan aktivitas penjualan.

Return on Equity

Berikut adalah grafik Return on Equity pada PT. Alam Sutera Realty Tbk. 


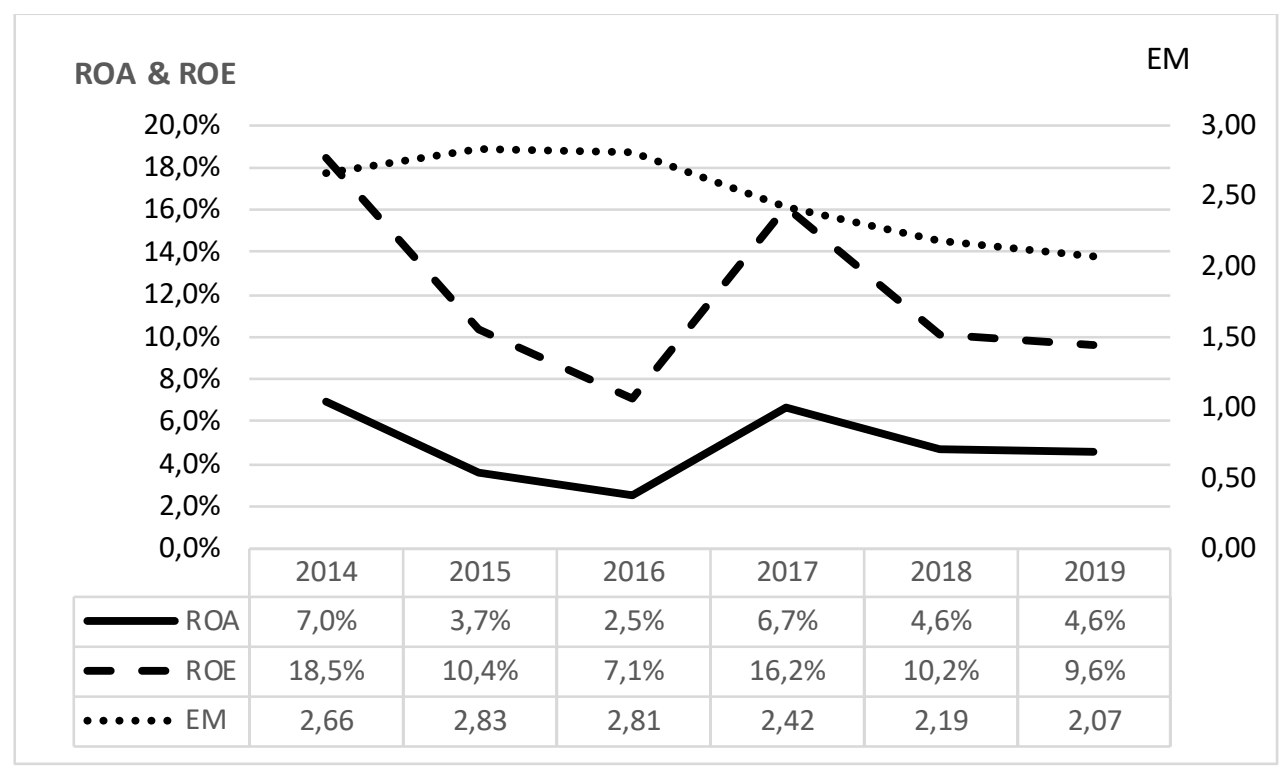

Grafik 7. Perbandingan ROA, ROE, dan EM ASRI

Return on Equity menunjukkan seberapa besar keuntungan yang dapat diperoleh atau dihasilkan perusahaan dari ekuitas atau modal yang dimiliki oleh perusahaan, dapat juga dikatakan bahwa rasio ini menunjukkan seberapa efektif dan efisiennya perusahaan dalam mengelola ekuitas atau modal yang dimilikinya sehingga dapat memperoleh laba yang lebih tinggi dengan ekuitas atau modal tersebut. Semakin tinggi nilai return on equity semakin tinggi pula laba yang dihasilkan perusahaan dari ekuitas atau modal yang dimilikinya. Pada grafik 7 terlihat nilai return on equity PT. Alam Sutera Realty, Tbk. mengalami penuruan yang cukup drastis dari tahun 2014 ke 2016, namun meningkat lagi dari tahun 2016 ke 2017, kemudian fluktuatif kembali. Rata-rata nilai return on equity perusahaan selama enam tahun adalah $12 \%$. Sehingga dapat dikatakan perusahaan cukup efisien dalam mengelola ekuitas atau modal yang dimilikinya.

\section{KESIMPULAN}

Berdasarkan hasil dan pembahasan yang telah diuraikan, maka dapat disimpulkan kinerja keuangan PT. Alam Sutera Realty, Tbk. sebagai berikut:

1. Tingkat likuiditas PT. Alam Sutera Realty, Tbk. yang diukur menggunakan current ratio tahun 2014-2019 menunjukkan kondisi yang cukup baik walaupun selama tahun 2015 hingga 2018 nilai current ratio < 1, namun perlu diketahui bahwa angka current ratio $<1$ tidak selalu menunjukkan bahwa perusahaan sedang di ambang kebangkrutan, karena perusahaan tersebut mungkin masih memiliki sumber dana lainnya.

2. Tingkat solvabilitas PT. Alam Sutera Realty, Tbk. yang diukur menggunakan total debt ratio dan debt equity ratio tahun 2014-2019 menunjukkan kondisi yang baik karena nilainya menurun yang berarti menurun juga resiko bagi para kreditur perusahaan.

3. Tingkat aktivitas PT. Alam Sutera Realty, Tbk. yang diukur menggunakan receivables turnover dan total asset turnover tahun 2014-2019 menunjukkan kondisi yang cukup efisien.

4. Tingkat profitabilitas PT. Alam Sutera Realty, Tbk. yang diukur menggunakan profit margin dan return on equity menunjukkan kondisi yang cukup efisien.

\section{DAFTAR PUSTAKA}


Dewi, Meutia.(2017). Analisis Rasio Keuangan untuk Mengukur Kinerja Keuangan PT Smartfren Telecom, Tbk.Jurnal Penelitian Ekonomi Akuntansi, volume 1, nomor 1

Fadil Abu Bakar, Muhammad dan Youlanda Hasan.(2018).Analisis Kinerja Keuangan Pada PT. PP (Persero) Tbk. Journal Economic and Business of Islam, volume 13, nomor 2

Harahap, S. S. (2009). Analisis Kritis Atas Laporan Keuangan. PT. Raja Grafindo Persada. Jakarta

Jumingan. (2009). Analisis Laporan Keuangan. Jakarta: Bumi Aksara.

Kasmir. (2010). Pengantar Manajemen Keuangan. Jakarta: Kencana Prenada Media Group. (2013). Analisis Laporan Keuangan. Jakarta: Rajawali Pers.

Munawir, S. (2010). Analisis Laporan Keuangan, Edisi 4. Yogyakarta: Liberty

Sugiyono. (2011). Statistika Untuk Penelitian. Bandung: Alfabeta (2014). Metode Penelitian Kuantitatif Kualitatif dan R\&D. Bandung: Alfabeta.

Wahrudin, Udin dan Opan Arifudin.(2020). Analisis Rasio Likuiditas, Solvabilitas, dan Rentabilitas PT. Alam Sutera Realty Tbk. Jurnal Proaksi, volume 7, nomor 2 www.idx.co.id ( Diakses 20) 